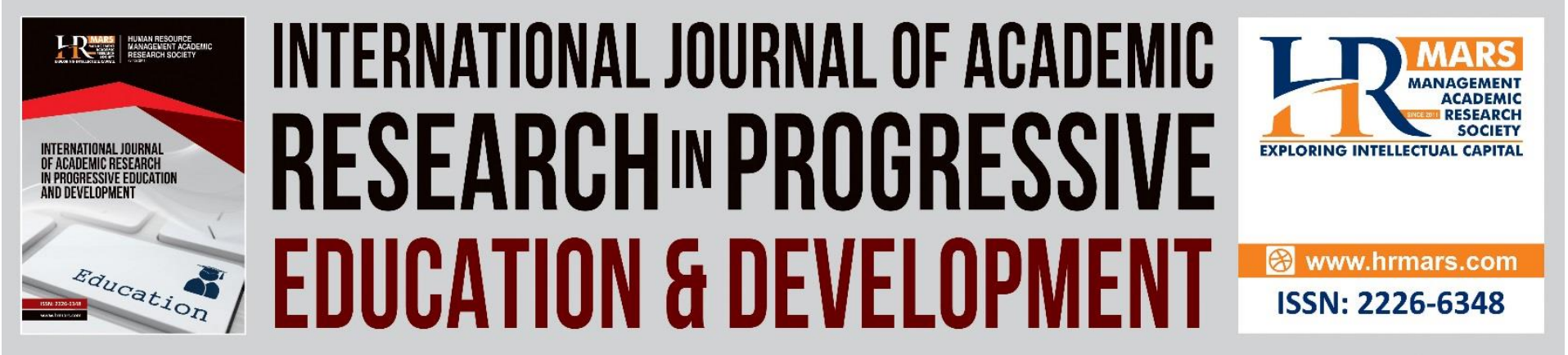

\title{
The Effectiveness of STAD Model Based on the Art Education Application Module on Students' Achievement and Attitudes
}

Othaya Kumaran Kandasamy, Al-Amin Mydin, Abdul Ghani Kanesan, Shaik Abdul Malik Mohamed Ismail

To Link this Article: http://dx.doi.org/10.6007/IJARPED/v10-i3/10572

DOI:10.6007/IJARPED/v10-i3/10572

Received: 02 June 2021, Revised: 06 July 2021, Accepted: 28 July 2021

Published Online: 17 August 2021

In-Text Citation: (Kandasamy et al., 2021)

To Cite this Article: Kandasamy, O. K., Mydin, A.-A., Kanesan, A. G., \& Ismail, S. A. M. M. (2021). The Effectiveness of STAD Model Based on the Art Education Application Module on Students' Achievement and Attitudes. International Journal of Academic Research in Progressive Education and Development, 10(3), 150-160.

Copyright: (C) 2021 The Author(s)

Published by Human Resource Management Academic Research Society (www.hrmars.com)

This article is published under the Creative Commons Attribution (CC BY 4.0) license. Anyone may reproduce, distribute, translate and create derivative works of this article (for both commercial and non-commercial purposes), subject to full attribution to the original publication and authors. The full terms of this license may be seen at: http://creativecommons.org/licences/by/4.0/legalcode

Vol. 10 (3) 2021, Pg. 150 - 160 


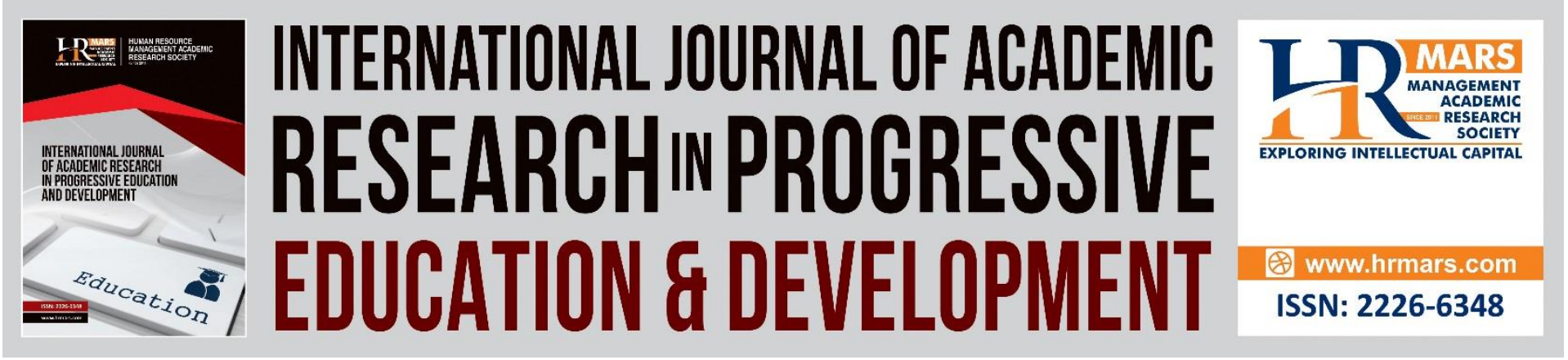

\title{
The Effectiveness of STAD Model Based on the Art Education Application Module on Students' Achievement and Attitudes
}

\author{
Othaya Kumaran Kandasamy, Al-Amin Mydin, Abdul Ghani \\ Kanesan, Shaik Abdul Malik Mohamed Ismail \\ School of Educational Studies, University Science Malaysia (USM) \\ Email: othayausm31@student.usm.my
}

\begin{abstract}
This study aims to measure the effectiveness of the STAD (Student Team Achievement Division) model of cooperative learning method based on the Art Education Application Module on the achievement and attitude of year four students in Tamil national type schools (SJKT). The research design employed a quasi-experiment method by dividing the research participants into two groups. The experimental group was taught using the STAD learning method based on the year four Art Education Application Module. Whereas the control group was taught using a conventional method based on textbooks. This study involved 62 Year Four students from two Tamil primary schools in the district of Kulim, Kedah. The study was conducted for eight weeks. The instruments used in this study are lesson plans based on STAD model learning methods, pre-tests, post-tests and attitude questionnaires. The results of this study were analyzed using independent t-test and two-way ANOVA. The findings of the study show that the experimental group taught using STAD learning method significantly increased the mean achievement score compared to the control group taught using conventional textbook-based methods. In addition, the experimental group attitude towards the art education subject showed a higher mean score compared to the control group. Finally, this study indicates major implications for year four SJKT students' improvement of achievement and attitude in the art education subject.
\end{abstract}

Keywords: Art Education, Experiment, STAD, Learning Methods, Attitude

\section{Introduction}

Art Education is an important component of the national curriculum at the primary school level. This subject contributes to the Malaysian Ministry of Education's efforts to educate a holistic and balanced student in line with the National Philosophy of Education. Art Education emphasizes on the four curriculum modules namely Art Language, Art Skills, Art Creativity and Innovation, as well as Art Appreciation. The content of the module is complementary so that students can apply the knowledge, skills and values learned from one module to another. Art Education provides students with a unique experience to explore their potential, build generic and social skills to become creative and innovative human beings (Standard Primary School Curriculum, 2018). 
Mastery of Content Standards (SK) and Learning Standards (SP) in the Art Education subject enables students to acquire the 21st Century Skills. Various approaches can be used in designing teaching and learning to achieve the learning standards of Art Education. Among the approaches that can be used in Art Education are inquiry-based learning; problem-based learning; module-based learning; themed approach and interdisciplinary approach. To achieve this goal, teachers play an important role in diversifying their teaching and learning methods (Bavani \& Mahamod,2017). In the Art Education lessons, the appropriate teaching and learning methods used by teachers directly enhances students 'understanding as it attracts students' interest. One of such important and effective methods is the cooperative learning method of the STAD model (Student Team Achievement Division). The STAD model of cooperative learning method is a student-centered method that gives students the opportunity to solve problems in groups (Malar, 2013).

Most studies show that students are uninterested in the Art Education study due to teachers' less effective and boring teaching methods. Non-innovative lessons conducted by teachers make students feel that Art Education is not a challenging subject. Therefore, innovative teaching and learning approaches are needed to make Art Education more interesting for students.

\section{Research Objective}

This research research comprises of 2 objectives:

RO1: To identify significant differences in mean achievement scores between experimental groups taught using the STAD model of cooperative learning method based on the Art Education Application Module and the control groups taught using textbooks.

RO2: To identify the effect of significant interaction between the attitudes of students in the experimental group taught using the cooperative learning method of the STAD model based on the Art Education Application Module and the control group taught using textbooks.

\section{Literature Review}

Cooperative Concept

Cooperative methods are one of the innovative teaching strategies (Chan, 2014). Cooperative methods take into account the cognitive, behavioral, emotional and social aspects of students. The level of learning in cooperative methods is not only for oneself, but also for others or friends. The five basic elements in cooperative learning are positive interdependence; face-to-face interaction; individual accountability for self-learning; collaboration skills; group processing (Vaughan, 2002). There are several types of strategies that can be used in cooperative learning. Among them are (1) group investigations (Group Investigation); (2) Student Team Achievement Division (STAD); (3) Jigsaw; (4) TeamAccelerated Instruction (TAI); (5) Team Games Tournament (TGT). In this study, the STAD model learning method (Student Team Achievement Division) is used. An important feature of the STAD model learning method is group presentations, demonstrations and individual interactive quizzes. In addition, group scores were evaluated based on group presentations and individual interactive quizzes. The winning group will be rewarded and praised (Malar, 2013). 
STAD Model

Cooperative learning methods are used in various age groups but they are very popular methods in primary school (Robert, 2015). One of the cooperative learning methods is the STAD model of cooperative learning method. This method is student-centered and based on the theory of social constructivism developed by Vygotsky. This method emphasizes cooperation among students and encourages group learning. Students will work in small groups and work together to complete assignments, share ideas and help each other solve problems. All group members need to be actively involved and the teacher acts as a facilitator. STAD's cooperative method is indeed stressful and focuses on student engagement as opposed to the usual teacher -centered method. Students will actually have a high level of confidence and motivation, dare to contribute ideas and give views and active involvement through the learning of this cooperative method of STAD while the teacher only acts as a facilitator. In conclusion, learning through the STAD Cooperative Method is the only method that is very interesting in accordance with the current situation today. Apart from that, the STAD Cooperative Method itself has many benefits to students and will indirectly improve school performance (Rahim@Ibrahim et al., 2017).

Review of Related Studies

The cooperative learning method of the STAD model encourages each group member to communicate with each other to express opinions, ideas or to obtain information. In addition, the STAD teaching method is also a collaborative activity between groups to complete group assignments and answer quiz questions spontaneously. Spontaneous quizzes provide an opportunity for students to gradually assess their mastery in the subjects taught (Malar, 2013). According to Altun (2015) cooperative learning cannot be taught orally. Even cooperative learning requires students' involvement to work together in groups, developing a product and evaluating them. Past studies have shown that cooperative learning can be used to improve student achievement (Vaughan, 2002; lyer, 2013).

The findings of Bavani and Mahamod (2017) prove that cooperative learning as a teaching approach reduces disciplinary problems that would interfere with the classroom learning. In addition, cooperative learning strategies are not only attractive to students but they also engage in active learning. The study of Ocampo and Bascos- Ocampo (2015) also proved that students who are exposed to cooperative learning methods of the STAD model have improved their attitudes and achievement in Physics. In addition, the study of Ismaon et al (2013) also showed that the cooperative learning of the STAD model has brought about a good change in students' attitudes towards mathematics.

The findings of Wyk (2012) study also show that cooperative learning of the STAD model forms a positive attitude; improving student achievement and motivation in economic subjects. In addition, Tran's (2014) study also stressed that cooperative learning has a positive effect on student achievement and knowledge consistency. In addition, his study shows that learning based on students' own assignments and involvement in the cooperative learning process maintains student achievement despite delays in testing. The study of Gull and Shehzad (2015) in the social sciences also supports the findings of other studies stating that student achievement increases in cooperative learning activities. The level of motivation of students in his study also increased when they helped each other and worked in groups. 


\section{Construction of Year Four Art Education Application Module}

The fourth year Art Education Application Module was built based on the ADDIE Model based on the Curriculum and Assessment Standard Document (DSKP), Art Education Year 4. The ADDIE Model was developed by Dick and Carry (1996). The ADDIE model is a design model that serves as a guideline towards the production of teaching and learning materials. The $A D D I E$ model is a teaching model that is often used as a basis for teaching and learning design models. The purpose of this designed model is to produce teaching plans and learning materials which ensure more effective and efficient delivery of a lesson. Based on the ADDIE model, there are five phases in the process of building this module. Art Education Application Module Year 4 is a module built to help students understand the content of Art Education subjects. This module is produced in the form of print media that contains a combination of notes and exercises broken down according to sub-topics as well as teaching and learning objectives to be achieved. The material production guide is presented in the form of colored pictorial sequences. This aims to attract students and make it easier for them to understand the lesson content without teacher's assistance.

\section{Research Method}

The design of this study applied the quasi-experimental method. The study was conducted for eight weeks. The study sample consisted of 62 year four students from two Tamil national type schools in Kulim district, Kedah. A total of 32 subjects from school A were selected as the experimental group. Meanwhile, 30 subjects from school B were selected as the control group. Each school represents a study group so that the teaching given to one group does not affect the other group. Subjects from both groups were students with almost the same level of achievement. The experimental group was taught using the cooperative learning method of the STAD model (Student Team Achievement Division) guided by the Art Education Application Module and the control group is taught using textbooks.

In this study, two types of instruments were used. That is, pre-test and post-test questions to measure student achievement. In addition, the questionnaire is adapted from the questionnaire The Aiken Attitude Scale (Tran, 2013) is used to measure student attitudes. The validity of pre-test and post-test is done by an experienced committee head. Validity of Art Education Application Module and attitude questionnaire were conducted by two lecturers from the Art Education unit, IPGK. A pilot study was conducted to measure the reliability of pre-test and post-test questions as well as attitude questionnaire items. This is to ensure that students can understand all the instructions and requirements of the question.

Researchers have trained teachers who teach experimental groups about the steps of the STAD model cooperative learning method. The experimental group teachers were provided with teaching topics, lesson and learning plans as well as teaching aids for cooperative learning methods of the STAD model for eight weeks. While the control group teacher was only provided with a textbook with the same teaching topic as the experimental group teacher. In the first week the experimental group and the control group were given pre-tests and attitude questionnaires. From the second week to the seventh week the experimental group was taught using the cooperative learning method of the STAD model. While the control group was taught using conventional methods. In the eighth week the experimental group and the control group were given post-tests and attitude questionnaires. Researchers 
DEVELOPMENT

Vol. 10, No. 3, 2021, E-ISSN: 2226-6348 @ 2021 HRMARS

have observed the teaching and learning of the experimental group and the control group four times to ensure that the teachers have followed the teaching and learning steps that have been provided.

\section{Findings}

Descriptive Data Analysis

Demographic Information of the Study Sample

The subjects of this study consisted of 62 students who are studying in two national Tamil type schools in Kulim District, Kedah. The study was divided into two groups, namely the experimental group and the control group. A total of 32 subjects of the experimental group were given treatment using the cooperative learning method of the STAD model based on the Art Education Application Module for the fourth year. A total of 30 control group subjects were taught using textbooks. Table 1 shows the descriptive statistical results of the demographic variables of the students involved in this study.

\section{Table 1}

Frequency Distribution and Percentage of Study Subjects

\begin{tabular}{|c|c|c|c|}
\hline \multirow{2}{*}{ Group } & & & \multirow{2}{*}{$\mathrm{F}$} \\
\hline & Men & Women & \\
\hline Experiment & 12 & 20 & 32 \\
\hline \multirow[t]{3}{*}{ Control } & $(37.5 \%)$ & $(62.5 \%)$ & 30 \\
\hline & 14 & 16 & \\
\hline & $(46.7 \%)$ & (53.3\%) & \\
\hline Total & $\begin{array}{c}26 \\
(41.9 \%)\end{array}$ & $\begin{array}{c}36 \\
(58.1 \%)\end{array}$ & 62 \\
\hline
\end{tabular}

Table 1 shows that a total of 12 students (37.5\%) were male subjects and 20 students (62.5\%) were female subjects involved in the treatment of the experimental group. While the control group consisted of 14 students (46.7\%) were male subjects and 16 students (53.3\%) were female subjects. All students involved in this study were 10 years old.

\section{Inference Statistical Analysis}

The First Zero Hypothesis of the Study

Ho1: There is no significant difference in the mean achievement score between the experimental group taught using the STAD model cooperative learning method based on Art Education Application Module with the control group taught using textbook. 
INTERNATIONAL JOURNAL OF ACADEMIC RESEARCH IN PROGRESSIVE EDUCATION AND

DEVELOPMENT

Vol. 10, No. 3, 2021, E-ISSN: 2226-6348 @ 2021 HRMARS

Table 2

Mean Pre-Test and Post-Test Achievement Scores

\begin{tabular}{lccccc}
\hline \multirow{2}{*}{ Group } & $\mathrm{N}$ & \multicolumn{2}{c}{$\begin{array}{c}\text { Pre- } \\
\text { Test }\end{array}$} & \multicolumn{3}{c}{ Post Test } \\
\cline { 2 - 6 } & & Min & SD & Min & SD \\
\hline Experiment & 32 & 30.14 & 8.53 & 76.23 & 10.70 \\
Control & 30 & 26.45 & 10.44 & 48.57 & 12.09 \\
\hline
\end{tabular}

Table 2 shows the mean pre-test achievement scores for the experimental group $(N=32)$ are $(M=30.14, S D=8.53)$ while the mean post-test achievement score is $(M=76.23, S D=$ 10.70). This shows an increase in the mean score for the experimental group is 46.09. Next, the mean achievement score for the pre-control group test $(N=30)$ is $(M=26.45, S D=$ 10.44 ) while the mean post-test achievement score is $(M=48.57, S D=12.09)$. The mean increase for the control group was 22.12. This means that the mean difference in achievement score for the experimental group is higher compared to the mean difference in achievement score for the control group.

Table 3

T-Test: Effects of Experimental Group Teaching and Learning with Control Group

\begin{tabular}{lcccccc}
\hline Group & $\mathrm{N}$ & Min Beza & SD & Value- $\mathrm{t}$ & $\mathrm{df}$ & $\mathrm{p}$ \\
\hline Experiment & 32 & 46.09 & 10.13 & 9,126 & 60 & \multirow{2}{*}{0.000} \\
Control & 30 & 22.12 & 9.85 & & & \\
\hline
\end{tabular}

Significant level of $p<0.05$

Table 3 shows the mean differences for the experimental group $(M=46.09, S D=10.13$ ) compared to the control group ( $M=22.12, S D=9.85)$. Exams Levene's shows the existence of similar variance between two groups of students namely $(F(2,60)=0.84, p=0.332)$ at significant levels $p<0.05$. Moreover, the independent $t$-test showed that there was a significant difference between the mean scores of the experimental group and the control group $t=9.126, d f=60, p=0.000)$. This means that the null hypothesis (Ho1) can be rejected. This indicates that the experimental group taught using the STAD method guided by the Art Education Application Module helps the subject to get a higher and significant achievement score compared to the control group subject taught using textbook.

\section{The Second Null Hypothesis of the Study}

Ho2: There was no significant interaction effect between group student attitudes experiments taught using the cooperative learning method of the STAD model guided by the Art Education Application Module with the control group taught using textbooks. 
INTERNATIONAL JOURNAL OF ACADEMIC RESEARCH IN PROGRESSIVE EDUCATION AND

DEVELOPMENT

Vol. 10, No. 3, 2021, E-ISSN: 2226-6348 @ 2021 HRMARS

Table 4

Two-Way ANOVA Test Comparison of Achievement Levels based on Student Attitude

\begin{tabular}{llllll}
\hline Main Impact & $\begin{array}{l}\text { Amount } \\
\text { Power } \\
\text { Two }\end{array}$ & $\mathrm{df}$ & $\begin{array}{l}\text { Min } \\
\text { Power } \\
\text { Two }\end{array}$ & Value F & $\begin{array}{l}\text { Level } \\
\text { Significant } \\
(\mathrm{p})\end{array}$ \\
\hline Group & 6879.82 & 1 & 6879.82 & 52.10 & 0.000 \\
Attitude & 155.02 & 1 & 155.02 & 1,174 & 0.283 \\
Group $^{*}$ & 11.89 & 1 & 11.89 & 0.090 & 0.765 \\
Attitude & 8451.05 & 58 & 132.05 & & \\
Error & 298853.00 & 62 & & & \\
Amount & & & & & \\
\hline
\end{tabular}

Significant level of $p<0.05$

Table 4 shows that there is a significant difference between the mean post-test score scores for the groups taught using the STAD model cooperative learning method based on the Art Education Application Module with textbook teaching $F(1,58)=52.10, p=0.000$. Furthermore, there was no significant difference between the mean post-test score scores according to the low attitude level and the high attitude level $F(1,58)=1.174, p=0.283)$. The subjects of the experimental group taught using the cooperative learning method of the STAD model based on the Art Education Application Module gave a higher reaction in the attitude level compared to the control group taught using textbooks. Finally, table 5.4 also shows that there is no significant interaction effect between the experimental group taught using STAD model cooperative learning method based on Art Education Application Module with control group taught using textbook where the level of attitude in terms of mean score of post test scores $(1,58)=0.090, p=0.765$. Therefore, the formed null hypothesis (Ho2) is accepted. Figure 5.1 shows a graph of the effect of interaction between groups with attitude levels.

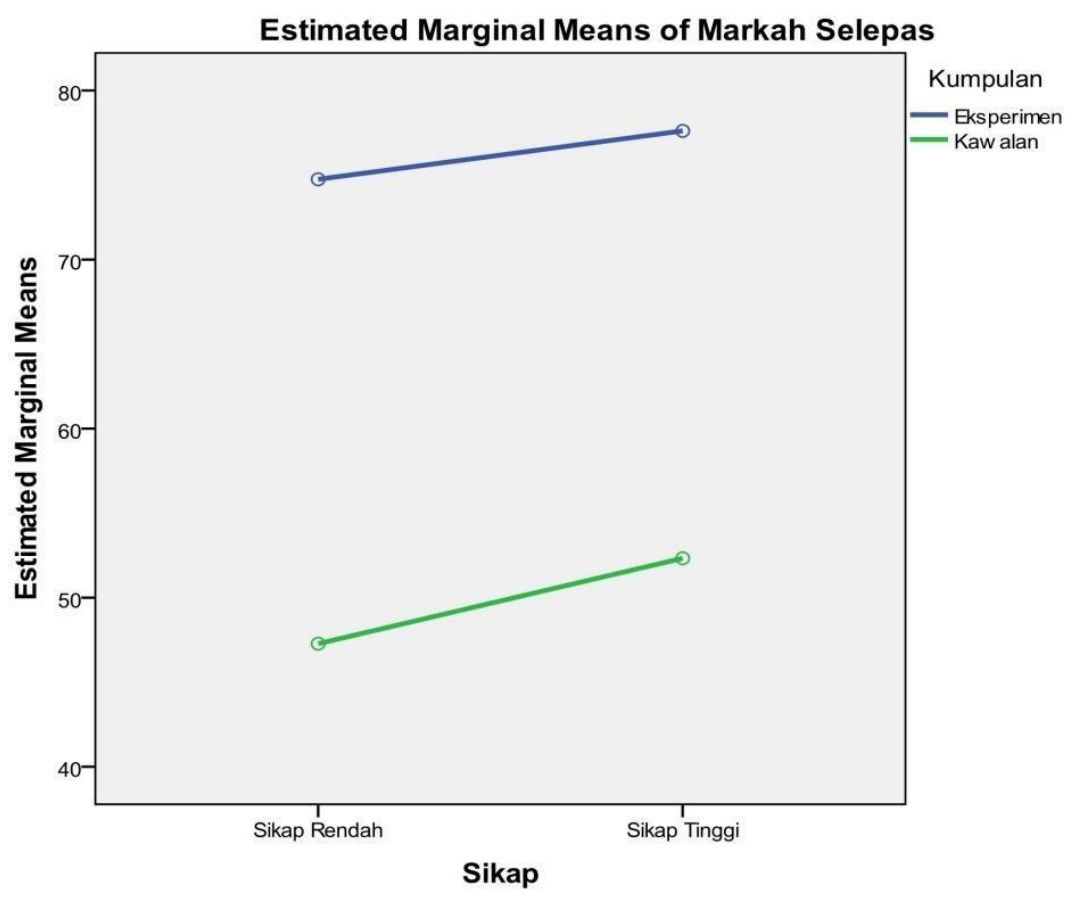

Figure 1: Graph of the Effect of Interaction between Groups and Levels Student Attitude 


\section{Discussion}

The findings show that the subjects of the experimental group taught using the cooperative learning method of the STAD model based on the Art Education Application Module have obtained a higher and significant mean score of achievement compared to the subjects of the control group taught using textbooks. The findings of this study are in line with the findings of the study (Vaughan, 2002; Malar, 2013; Iyer, 2013). In addition, this study also showed an increase in the mean score of the subjects of the experimental group taught using the cooperative learning method of the STAD model based on the Art Education Application Module gave a higher reaction in the attitude level compared to the control group taught using textbooks. The findings of this study support the findings of the study (Van Wyk, 2012; Zainun Ismaon et al., 2013; Tran, 2014; Gull \& Shehzad, 2015; Ocampo \& Bascos-Ocampo, 2015; Bavani \& Mahamod,2017). Overall, the findings of this study indicate that the use of cooperative learning methods of the STAD model in the teaching and learning of art education has a positive impact on student achievement and attitudes.

\section{Implications of The Study}

The use of appropriate methods will certainly have a positive impact on the pupil if the teacher has made a full and neat preparation for each teaching step to be delivered. This will create an active learning environment where all pupils engage in various fun activities. This will encourage more effective interaction in the more meaningful teaching and learning process. Based on the findings of this study, it is clear that art activities based on the STAD method can enhance the integration of learning domain among students in terms of cognitive development, affective construction and psychomotor management simultaneously. Systematic teaching and the use of appropriate methods can increase awareness and skill potential towards Arts Education (Plows, 2014).

The findings of this study have implications for the relevant parties, especially students, teachers and the school. Certain teaching and learning methods using teaching modules can improve students' academic achievement and attitude. In addition, the method of using teaching and learning modules in teaching can also help teachers to be facilitators to students. Teachers can guide students on how to use the correct teaching and learning modules in line with students' abilities. Art Education teachers are advised to build teaching and learning modules according to the ability of students. The school should also encourage teachers to build and use their own teaching and learning modules in the teaching and learning process. Besides, the school can organize inservice courses (LDP) related to the construction of effective modules towards improving academic achievement and student attitudes. Online teaching and learning modules can be developed so that the collection of teaching modules can be stored and accessed by students and teachers.

\section{Conclusion}

The results of this study show that the cooperative learning method of the STAD model based on the Art Education Application Module on the achievement and attitude of students in Art Education subject has a good effect. Therefore, it can be concluded that the use of the Art Education Application Module is suitable to be utilized as one of the teaching and learning strategies of Art Education. In addition, the teaching and learning process of Art Education can be implemented in a more organized and planned manner. 
Arts Education is a subject that emphasizes the development of students and becomes the pillar to give a paradigm surge to produce people that are balanced and harmonious in terms of intellectual, spiritual, emotional. The diversity of techniques and methods used in arts activities can stimulate the motivation and creativity of students. The study also proved that the art field seen in the aspect of art as a medium of communication and self-expression is one of the techniques that can be used in forming a more creative, innovative and productive human capital. Methods guided by arts education modules can enhance creativity and smooth the teaching and learning process. This method also provides complete guidelines so that teachers can implement student-centred teaching and give confidence to the students. Thus pupils can increase their ability to develop themselves and explore artistic creativity to produce original and unique ideas in artworks (Zakaria and Anuar, 2019).

Teaching and learning that uses cooperative learning methods of the STAD model based on the Art Education Application Module open a wide space for students to explore their own learning. Meanwhile, teachers can act as facilitators who control student learning. This study has given clear implications for more enjoyable lessons which encourages students' active involvement in Art Education. Finally, the researcher hopes that further research contributes more inputs in terms of the cooperative learning method of the STAD model based on the Art Education Application Module in the Art Education teaching and learning.

\section{References}

Ab Rahim@Ibrahim, A., Zalay@Zali, A. A., \& Khairani, M. Z. (2017). Kaedah Pembelajaran Koperatif Model STAD Meningkatkan Pencapaian Pelajar Dalam Penghasilan Catan Cat Air. Jurnal Seni Dan Pendidikan Seni, 5, 68-75.

Altun, S. (2015). The effect of cooperative learning on students' achievement and views on the science and technology course. International Electronic Journal of Elementary Education, 7(3), 451-468.

Somasudram, B., \& Mahamod, Z. (2017). Keberkesanan pembelajaran koperatif terhadap pencapaian dan motivasi murid sekolah menengah dalam pembelajaran Bahasa Melayu. Malay Language Education ournal, 7(1), 2180-4842.

Chan, K. W. (2014). Cooperative learning in a Hong Kong primary school: perceptions, problems and accommodation. Intercultural Education, 25(3), 216-228. https://doi.org/10.1080/14675986.2014.911805

Dick, W., Carey, L. (1996). The Systematic Design of Instruction. (4th Ed.). New York: Harper Collins College Publishers.

Gull, F., \& Shehzad, S. (2015). Effects of Cooperative Learning on Students' Academic Achievement. Journal of Education and Learning (EduLearn), 9(3), 246. https://doi.org/10.11591/edulearn.v9i3.2071

Iyer, R. B. (2013). Relation between Cooperative Learning and Student Achievement. International Journal of Education and Information Studies., 3(1), 21-25.

Kurikulum Standard Sekolah Rendah. (2018). Pendidikan Kesenian Tahun 4. Bahagian Pembangunan Kurikulum. Putrajaya: Kementerian Pendidikan Malaysia.

Malar, M. (2013). Kesan Kaedah STAD Terhadap Ketekalan Pengetahuan Sejarah Dan Kemahiran Sosial Murid Tingkatan Dua Malar. Seminar Pendidikan Sejarah Dan Geografi UMS, 2013, 29-30. 
Ocampo, R. O., \& Bascos-Ocampo, R. (2015). Effectiveness of Students' Team Achievement Division on Students' Attitude Towards Physics. Asia Pacific Journal of Multidisciplinary Research, 3(4), 112-117. Retrieved from http://www.apjmr.com/wpcontent/uploads/2015/10/APJMR-2015-3.4.3.14.pdf

Plows, J. (2014). There's more to it! The visual art realm of three-year-old children. He Kupu, $3(5), 46-54$.

Robert, E. S. (2015). Cooperative learning in elementary schools. Education., 3-13. https://doi.org/10.1080/03004279.2015.963370

Tran, V. D. (2014). The Effects of Cooperative Learning on the Academic Achievement and Knowledge Retention. International Journal of Higher Education, 3(2), 131-140. https://doi.org/10.5430/ijhe.v3n2p131

Tran, V. D. (2013). Effects of Student Teams Achievement Division (STAD) on Academic Achievement, and Attitudes of Grade 9th Secondary School Students towards Mathematics. International Journal of Sciences, 2(04), 5-15. Retrieved from http://www.ijsciences.com

Van Wyk, M. M. (2012). The effects of the STAD-Cooperative Learning Method on student achievement, attitude and motivation in economics education. Journal of Social Sciences, $33(2), 261-270$.

Vaughan, W. (2002). Effects of cooperative learning on achievement and attitude among students of color. Journal of Educational Research, 95(6), 359-364. https://doi.org/10.1080/00220670209596610

Ismaon, Z., Iksan, Z., \& Othman, N. (2013). Kesan Pembelajaran Koperatif Model STAD Ke Atas Sikap Terhadap Matematik. Jurnal Pendidikan Matematik, 1(1), 11-18.

Zakaria, A. F., \& Anuar, R. (2019). Adaptation of the Creative Development Theory in Developing Creativity Among Year 1 Students. Jurnal Seni Dan Pendidikan Seni, 5. Retrieved from

https://ejournal.upsi.edu.my/index.php/JSPS/article/view/2269 